\title{
Scholarly Communication and Authorship Patterns in Language Research: Evidences from Citation Analysis of Language Theses in Nigeria
}

\author{
Ifeanyi J. Ezema \\ Post-Doctoral Fellow, Department of Information Science, University of South Africa \\ Nnamdi Azikiwe Library, University of Nigeria Nsukka \\ ifeanyi.ezema@unn.edu.ng orezemaji@unisa.ac.za \\ DOI//http://dx.doi.org/10.4314/gjds.v13i2.1
}

\begin{abstract}
Investigation into citation and authorship patterns in language and linguistics research is of serious interest to librarians and researchers. The purpose of this paper is to examine scholarly communication behaviour in languages using theses and dissertations to enhance collection development policy in linguistics research. Bibliometric and informetrics indicators were used to examine a total of 87 theses and dissertations submitted to the Department of Linguistics and Nigerian Languages from 2005 to 2014. A retrospective descriptive study was conducted using bibliometric indicators such as types of cited sources, timeliness of cited sources, authorship pattern, rank list of frequently cited books and degree of research collaboration. A total of 5084 bibliographic references were extracted from the theses with an average of 58.4 citations per theses. Books and monographs dominated the entire citations with $63.6 \%$ while journal citations were $17.9 \%$. Electronic resources accounted for $15.4 \%$ of the citations. This study provides useful evidence to librarians who would be interested in developing the language library collections. Monographs have been found to be more useful for language researchers and collection development librarians will be guided in policy formulation particularly academic libraries where language research needs to be supported. There has been paucity of citation studies in the humanities generally and linguistics in particular. This study is an original research adopting bibliometric approach to examine scholarly communication in language and linguistics using University of Nigeria, Nsukka as a case study.
\end{abstract}

Keywords: Bibliometrics, Citation Analysis, Authorship Pattern, Information Science, Language Research, Scholarly Communication 


\section{Introduction}

Language plays very critical roles in the overall national development and global integration. This is why linguists are interested in the development of languages through research and enunciation of language policies in many cultures all over the world. Language features in different developmental discourses depending on whether it is conceived as a functional device for communication and technical education, or as a vehicle and manifestation of culture (Fardon \& Fumiss, 2003). There are at least two areas in which language is crucial to national development: literacy and communication (Bamgbose, 2003) for there is an obvious link between literacy and development. For instance, the world's poorest countries are also the countries with the highest rates of illiteracy. Since literacy liberates untapped human potentials and leads to increased productivity and better living conditions, it is not surprising that countries with the highest rates of literacy are also the most economically advanced. The socio-economic and political life of any individual is propelled by the use of language. As a result of this Olaoye (2009) remarked that man's access to knowledge is facilitated through the use of languages.

According to Rufai (2000) language is defined as 'the spoken means by which human beings communicate and/or interact.' However, Trudgill (1983) believes that the purpose of language goes beyond communication since other animals can as well communicate without the use of a language. For people of the same linguistics background, language acts as a very strong unifying tool and reflects a kind of identity for them. In such environment, language is looked upon as an agent of social control since it is rulegoverned and any breach of such rule is appropriately sanctioned (Gilbert, 2008). Every language has a speech norm that must be observed so as to avoid communication breakdown.

Language is often used to advance international political and economic power play in the global environment. Gilbert (2008) has remarked that every language in a unique way defines how things are talked about and which concepts for making sense of the world are fundamentally assumed. He argued that language is a very important tool in the exercise of power. The owner of a domineering language automatically becomes more powerful than those whose language is spoken by the minority. Observations have shown that more than eighty percent of global information is in the language of the Western countries, that is, English language and as a result major international discourses are conducted in the languages of domineering super powers. In addition to this function, Ogundare (2004) has noted that language plays very critical roles in the capacity of man to conquer and civilize his environment. It is a very powerful instrument of colonization and neo-colonization. The United States and other European countries have successfully used this in establishing their influence on other countries of the world particularly the developing countries. The socio-economic and 
political functions of any language are usually dependent on the extent of research and utilization of such language. Such researches are made available to the global academic community through scholarly communication processes.

Scholarly communication is the processes of sharing research results through publication and other processes. Scholars who participate in the scholarly communication process perform different roles, not only as authors or readers. Borgman and Furner (2002) identify four different roles for researchers, namely: as writers, as linkers (e.g. to cite), as submitters (chooser of publication channel), and collaborators. Some other scholars also participate in the peer review mechanism as a form of quality control of the paper. These roles and their importance vary across scholarly fields and academic cultures.

Research activities and scholarly communication in Nigeria are generally low as bibliometric study by Ocholla and Ocholla (2007) shows that African scholars are behind the rest of the world in scholarly productivity. Similarly, Olukoju (2004) has regretted that scholarly publications in Nigeria have been decreasing since the 1980s. This development has often been associated with the pattern of information generation and dissemination in the global community. An effective and reliable method of examination of scholarly communication process in languages is to look at information resources researchers use in the field, citations and authorship patterns. This guides researchers and other stakeholders like librarians on how to support research through acquisition of research materials in the area. Citation analysis is a reliable method of determining the information resources which researchers use in a particular field with the intention of developing core literature for acquisition in the field. It is also useful in establishing the pattern of research communication in the field as well as the publication patterns and research impacts of scholars (Shaw \& Vaughan, 2008; Singh, 2013).

Citation analysis has often relied on data from the Institute of Scientific Information (ISI) which was founded by Eugene Garfield in 1958 using three citation indexes (SCI, SSCI, A\&HCI) which provide available information on systematic analysis of impact and influence of scholarly literature. They have long been the most common source data for citation analysis. However, Moed (2005) and Meho (2007) have observed that the indexes have limited coverage of citations; which is restricted only to the journal literature marginalizing other kinds of scholarly publications such as books, chapters in edited books, conference proceedings, technical reports, and patents. This implies that it is skewed against social science and humanities in favour of scientific fields covering mainly English language titles from North America and Western Europe. These are serious flaws, particularly to the researchers in humanities and the social sciences. As a result of this, citation studies have been conducted with journals not included in the databases (Singh, 2013; Ezema \& Asogwa, 2014) while others resorted to the use 
of theses and dissertations (Gooden, 2001; Tonta \& Al, 2006; Riahinia, 2010; Fasae, 2011; Banateppanvar \& Biraddar, 2013; Ezema \& Ugwuanyi, 2014; Gasparotto, 2014; Abeyrathne, 2015) while conducting citation analysis.

In view of this development, this study relied on theses and dissertations as source data. Theses and dissertations have been found to contain results of preliminary studies or discussions of future research directions that would be very valuable to upcoming researchers in that area (Eaton, cited in Kiondo 2004). The doctoral theses in particular form the bulk of the academic programme and play very significant roles in higher education. In The Role and Nature of the Doctoral Dissertation: A Policy Statement, the Council of Graduate Schools (1991) remarked that "there is no question that, in the view of the faculty, students, and administrators participating in this study, the doctoral dissertation, as a demonstration of a student's ability to carry out research independently, defines the essence of the Ph.D degree." In corroborating this, Boyer cited in Gooden described the dissertation as the "capstone to formal academic training process." Similarly, Barry (1997) argued that a successful doctoral student tends to be comprehensive and up-to-date in reviewing the literature. Doctoral theses therefore are invaluable primary literature which cannot be ignored in the scholarly environment. This is because the doctoral thesis is an embodiment of primary research finding that has passed through a meticulous and rigorous peer review process through series of panels of experts. Kiondo (2004) has equally underscored the importance of theses and dissertations in the scholarly communication circle. According to her they are considered as valuable sources of research materials for not only students and scholars, but also for policy makers and other people who benefit from research findings.

Language studies in the University of Nigeria, Nsukka started in 1981 with the establishment of Department of Linguistics and other Nigerian languages, 21 years after the establishment of the university in 1960 (University of Nigeria Calendar, 2008). Available records of theses submission show that the department has produced over one hundred and fifty theses and dissertations since inception.

The purpose of this paper is to examine the citations and authorship patterns in language research using theses and dissertations submitted to Department of Linguistics and Nigerian Language, University of Nigeria Nsukka. Specifically, the paper intends to interrogate the authorship pattern (sole or multiple) sources, language, quantity, currency and frequency of sources among others. Other include:

- Determine the year-wise production of theses within the period under review;

- Find out the types of sources cited by language researchers;

- Determine the quantity of citation to electronic resources in language research; 
- Determine the language of cited sources in the theses;

- Find out the age of the cited sources;

- Examine the authorship pattern in language research;

- Determine the authorship and degree of collaboration among authors;

- Develop a rank list of frequently cited books in language research.

\section{Literature Review}

Citation analysis is an aspect of bibliometric studies which deals with analysis of references listed at the end of a research work, usually done through citation counts. It is a wide ranging area of bibliometrics that studies the relationship between a work and documents citing the work or an author and other authors citing him (Gooden 2001; Aina \& Ajiferuke, 2002). Citation analysis has been applied in several disciplines and geographical regions to determine types of sources used in research, citation patterns of researchers, authorship patterns timeliness of cited sources, rank list of journals among other issues and variations in information sources used in different fields of study.

Gooden (2001) explained that citation analysis is "an excellent unobtrusive method to determine which resources researchers are using." Citation analysis is associated with Eugene Garfield (cited in Leydesdorff 2011) who proposed a citation index that offered a new approach to subject control of the scientific literature. Garfield argued that there exist some relationships between a particular article and its references. This similarity between an article and its references is the cornerstone of citation analysis since this relationship is of great interest to scholars. Meho (2007) noted that citation analysis as a branch of information science assumes that influential scholars and important works are cited more than the others. The belief is that references to a particular journal reflect a scholarly impact of that article on the author of the citing work. Another assumption is that the accumulated citations to a given author's work in some sense reflect the impact of that author on scholarship and research.

\section{Citation Patterns and Scholarly Communication in Languages}

Scholarly communication in languages and linguistics in Nigeria may not be different from other disciplines. However, the channel of communication and pattern of citations may be quite different from other fields. Channels of scholarly communication are usually through the journals, books, conference proceedings and later through online platform such as institutional repositories, blogs, social media among others (Heinzkill, 1980; Zwaan \& Nederhof, 1990; Georgas \& Cullars, 2005) which is typical of all humanities fields. Their reliance on books and monographs is so deep that it is doubtful 
whether there are core journals in languages. Few citation studies provide more glaring picture of the citation patterns in the languages and linguistics and the controversy on how to classify the field of linguistics. Tannen (1989) has argued that linguistics (the science and study of languages) can be "scientific, humanistic and aesthetic" and therefore has been regarded as "the most scientific of the humanities and the most humanistic of the sciences." Though Zwaan and Nederhof (1990) in their investigation concluded that theoretical linguistics reflects a publication pattern closer to the social sciences than the literary and historical studies, linguistics generally has been classified in the humanities (Georgas \& Cullars, 2005, Knieval \& Kellsey, 2005). Some linguists for example are historians of languages; others work quite closely with philosophers, anthropologists, sociologists and literary artists.

This controversy about its classification may have contributed to a very scanty study on the citation patterns of the linguists and literary scholars as has been reported by Karisson (1994) and Georgas and Cullars (2005). Karisson contends that humanities in general have not been favoured by citation analysis, but linguistics is one of the lowest of the humanities disciplines. His argument is that the culture and language bound fragmentation of the humanities is a serious problem from the perspective of citation analysis as "most small cultures and languages are not covered by standard citation indexes such as A\&HCI from Institute for Scientific Information (ISI). Another reason for this lack of coverage is that like other humanities fields, linguistics relies mainly on books and monographs, which are not in the data base of ISI. For example, in the investigation on the citations of Finnish linguists using a popular linguistics journal Virittaja, Karisson (1994) demonstrated that the first ten most cited works were books.

An investigation (Georgas \& Cullars, 2005) using Language and Linguistics Behavioural Abstracts (LLBA) and MLA bibliography indicates that the linguistics citation patterns relate to social sciences, with $49.7 \%$ citations to books and $42.8 \%$ to journal. This is contrary to humanities citations which range from $60 \%$ to $80 \%$ citations to books and monographs. An earlier study (Heinzkill, 1980) equally faults Georgas and Cullars' investigation. Using a total of 9556 references from 15 journals in English language and literature, Heinzkill reveals that $75 \%$ of the citations in the study were to books and $20 \%$ to journals and the remaining $5 \%$ to other materials. A recent study by Gasparotto (2014) also provides evidences that monograph remained heavily used in linguistics research. Ezema \& Asogwa (2014) also conducted a citation analysis of 884 papers from two linguistics journals. Of the 15,283 bibliographic references, $53.3 \%$ were citations to books and monographs; while $35.9 \%$ were journal citations and the remaining distributed to conference papers, theses and dissertations.

Linguists also cite older materials like other fields in humanities for instance, the studies of Karisson, (1994) and Gasparotto, (2014) indicate that a large proportion of 
publications cited were published between 1745 and 1910 and more than $60 \%$ of them were to books published between 1940 and 1970. Similarly, more than $70 \%$ of the cited sources in Ezema \& Asogwa's (2014) study exceeded ten years old. Another study by Nkiko and Adetoro (2007) examined timeliness of cited sources and found out that more than $60 \%$ of citations were less than ten years old. Georgas and Cullars (2005), in their study, also found that the ages of citations were between one and fifteen years, and more than $5 \%$ of the citations were published between 1600 and 1960, which suggests that old materials were fairly cited.

Studies have indicated no clear core journals in linguistics research. In a study by Heinzkill (1980), only very few core journals were identified in the study with the publications of Modern Language Association dominating the citations. The investigation also shows that citations in language and literature do not conform to Bradford's law of scattering, but the indication is that language and literature seem to value current materials. The study of Georgas and Culler (2005), however, failed to identify any set of core journals in the field contrary to Zwaan and Nederhof's who found ten core journals in linguistics. Evidences from Knievel and Kellsey's (2005) and Karisson's (1994) show that language and literary scholarship rely heavily on books and monographs, citing older publications, making use of essentially primary information sources and near absence of core journals.

\section{Citations and Authorship Patterns of Other Disciplines}

Some citation studies are conducted to determine authorship patterns and degree of collaboration (Vimala \& Reddy, 1996; Ezema \& Asogwa, 2012, Kumar \& Kumar, 2011; Pradhan, Panda \& Chabdrakar, 2011; Singh, 2013). The study of Vimala and Reddy revealed a dominance of multiple authorship patterns in Zoology, solo research also existed. Though proportion of single authored papers has shown a declining trend, the degree of collaboration in research was 0.75. Similarly, Ezema and Asogwa's (2012) found more multiple authors than single authors in Agricultural research, while Singh (2013) found more single authorship patterns $(65.92 \%)$ in the field of Library and Information Science. Singh \& Bebi (2013) also found more single authorship patterns (83.94\%) in the same field.

The study by Pradhan, Panda and Chandrakar (2011) which examined the trends and authorship pattern and author collaborative research in Indian chemistry literature indicates that the degree of collaboration (C) during the overall 10 years (2000-2009) was 0.03 , but the year - wise degree of collaboration is almost same in all the years of mean value 0.97. In the period under review, the multi-authorship articles were higher than single authorship. The study of Kumar and Kumar (2011) using Journal of Oilseed Research (JOR) found that collaboration coefficient is very high during all the years ranging from 
0.76 to 0.84 and more multiple authorship - an indication of high collaboration among scientists. However, humanities research has often shown more single authors than multiple authors as revealed by Thompson (2002).

Other citation studies have been conducted to develop rank lists of core journals. Udofia (1997) conducted citation analysis for selection of principal veterinary medical journals. The result of the study shows that Bulletin of Animal Health and Production in Africa is the most cited journal with 605 citations representing $66.2 \%$ of the entire citations. Another study by Okiy (2003) examined educational dissertations at Delta State University and developed a rank list of 18 most cited journals, 12 of which are published in the United States. A study by Dabrishus (2005) analyzed the citation pattern of Classics using three journals and identified a total of 63 most frequently cited journals with Classical Quarterly ranking first. Enger (2009) also employed citation analysis to develop core books for collection development in the Social Sciences and found that the methods accounted for circulation of nearly $95 \%$ of the social science collection.

Other citation studies have been employed to determine the use of electronic resources in research communication. For example, Harter (1996) conducted a citation analysis to determine the impact of electronic journals on scholarly communication using thirtynine scholarly journals that began electronic publications not later than 1993. Findings show that great majority of scholarly e-journals have had essentially no impact on scholarly communication in their respective fields. Only eight of the 39 e-journals (20.5\%) have been cited ten or more times over their lifetimes. Similarly, Zhang (1998) investigated the impact of internet-based electronic resources on formal scholarly communication in the area of library and information science and found that of the 1,175 citations, $7.49 \%$ articles have electronic references while the average e-reference was $3.78 \%$. The study concludes that the impact of e-citation is very low when compared with the print types.

Another investigation by Herring (2002) revealed that $8 \%$ of the electronic citations were to such unpublished or ephemeral resources and $27 \%$ of the electronic citations were categorized as interdisciplinary. Jan's (2009) investigation on the use of electronic resources in Library Trends revealed that $44.51 \%$ print books were cited compared to o\% electronic books and $44.04 \%$ print journals were cited as against $11.82 \%$ electronic journals. In another recent study, (Singh 2013) citation to electronic resources was 25.8\%. Perhaps the low citations to electronic resources made Ezema (2011) to call for building of open access institutional repository in African universities to facilitate access to research materials scattered in many universities. 


\section{Methods}

The research method adopted for this study was citation analysis. This method is appropriate for the analysis of cited reference sources in language theses in the University of Nigeria, Nsukka. A total of 87 theses and dissertations submitted from 2005 to 2014 to the Department of Linguistics and Nigerian Languages of the university found in the university library were used for the study. The citations documented as references in the theses were used. The classification of sources cited was developed following earlier citation studies found in earlier literature (Georgas \& Cullars, 2005; Karisson 1994). Citations documented as references were extracted and analyzed in relationship to the objectives of the study. Items of the same theses which were cited more than once in references were counted as one. The data were analyzed using descriptive statistics of frequency and percentage and presented in tables and charts. The rank list of most frequently cited books was determined by inclusion of all the books that met the average citations of 63.2 to books and monographs. To determine the collaboration coefficient among the authors, the paper adopted the formula by Subramanyan (1983) as follows:

The degree of collaboration $C=$

Where $C$ = Degree of collaboration in a discipline

$N m=$ Number of multiple authored papers in a discipline

Ns $=$ Number of single authored papers in a discipline 


\section{Results}

Table 1: Year wise distribution of the theses

\begin{tabular}{|l|l|l|}
\hline Year & No of theses & $\%$ \\
\hline 2005 & 6 & 6.9 \\
\hline 2006 & 9 & 10.3 \\
\hline 2007 & 11 & 12.6 \\
\hline 2008 & 8 & 9.2 \\
\hline 2009 & 12 & 13.8 \\
\hline 2010 & 9 & 10.3 \\
\hline 2011 & 10 & 11.5 \\
\hline 2012 & 7 & 8.0 \\
\hline 2013 & 8 & 9.2 \\
\hline 2014 & 7 & 8.0 \\
\hline Total & 87 & 99.9 \\
\hline
\end{tabular}

Table 1 presents the result for the year wise distribution of the theses used for the study. From the Table one can observe that the highest number of theses was recorded in 2009 with $13.8 \%$ followed by 2007 with $10.3 \%$. The least number of theses was recorded in 1997 with $5.7 \%$. It can be seen from the table that the theses are not evenly distributed over the years.

Table 2: Type of cited sources

\begin{tabular}{|l|l|l|}
\hline Types of Sources & No of citations & $\%$ \\
\hline Books/monographs & 3232 & 63.6 \\
\hline Journals & 909 & 17.9 \\
\hline Theses and dissertations & 408 & 8.0 \\
\hline Conference/Seminar papers & 332 & 6.5 \\
\hline Lecture Notes & 49 & 1.0 \\
\hline Reports & 44 & 0.9 \\
\hline Govt. Pub & 35 & 0.7 \\
\hline News Pub. & 32 & 0.6 \\
\hline Interview & 19 & 0.4 \\
\hline Inaugural lectures & 17 & 0.3 \\
\hline Mimeograph & 7 & 0.1 \\
\hline Total & 5,084 & 99.9 \\
\hline
\end{tabular}

The result of the types of cited sources is presented in Table 2. It can be seen from the table that books and monographs received the highest citations (63.6\%) followed by journals (17.9\%) and then theses (8\%). The least cited sources are interview (0.4\%), inaugural lectures (0.3\%) and mimeograph (0.1\%). The findings reveal that books and monographs are mainly used by language researchers. 
Table 3: Citations to electronic resources

\begin{tabular}{|l|l|l|l|}
\hline Types of Resource & No of e-citations & $\begin{array}{l}\text { \%of e-resources } \\
\mathrm{N}=781\end{array}$ & $\begin{array}{l}\text { \% of total citations } \\
\mathrm{N}=5084\end{array}$ \\
\hline Books/monographs & 121 & 15.5 & 2.4 \\
\hline Journals & 537 & 68.8 & 10.6 \\
\hline Theses and dissertations & 40 & 5.1 & 0.8 \\
\hline Conference/Seminar papers & 33 & 4.2 & 0.7 \\
\hline Reports & 21 & 2.7 & 0.4 \\
\hline Govt. Pub & 18 & 2.3 & 0.4 \\
\hline Newspapers/magazines & 9 & 1.2 & 0.2 \\
\hline Inaugural lectures & 2 & 0.2 & 0.04 \\
\hline Total & 781 & $\mathbf{1 0 0}$ & $\mathbf{1 5 . 4}$ \\
\hline
\end{tabular}

The results of citations to electronic resources is presented in table 3 , where citations to e-journals contributed over $68 \%$ of the overall e-citations, followed by citations to e-books with $15.5 \%$. Other electronic resources cited are theses and dissertations $(5.1 \%)$, conference/ seminar papers $(4.2 \%)$, reports $(2.7 \%)$, government publications (2.3\%), news publications (1.2\%) and inaugural lectures (0.2\%).

Table 4: Timeline citations to electronic resources

\begin{tabular}{|l|l|l|}
\hline Year & E-citations & \% \\
\hline 2005 & 23 & 2.9 \\
\hline 2006 & 48 & 6.1 \\
\hline 2007 & 57 & $7 \cdot 3$ \\
\hline 2008 & 67 & 8.6 \\
\hline 2009 & 79 & 10.1 \\
\hline 2010 & 84 & 10.8 \\
\hline 2011 & 92 & 11.8 \\
\hline 2012 & 101 & 12.9 \\
\hline 2013 & 109 & 14.0 \\
\hline 2014 & 121 & 15.5 \\
\hline Total & 781 & 100 \\
\hline
\end{tabular}

In table 4, the timeline citation to e-resources is presented. It is evident from the table that there has been progressive increase in citation to electronic resources from $2.9 \%$ in 2005 to $15.5 \%$ in 2014 . This implies the language researchers are gradually adopting the use of the Internet in their research activities. Figure 1 below provides a graphical illustration of the trends in electronic resources citations among language researchers within the period under review. 


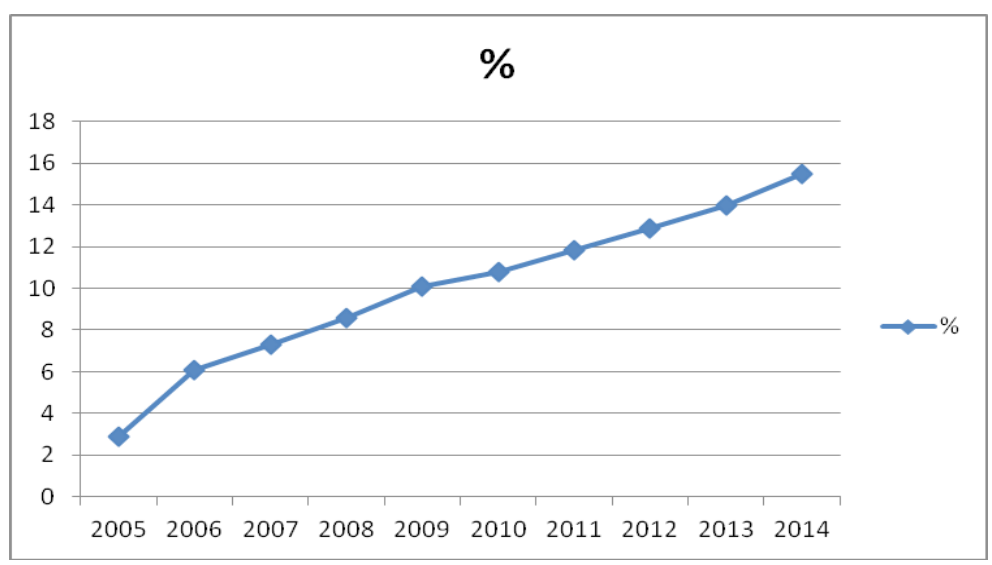

Figure 1: Trend of electronic citations

Table 5: Language of cited sources

\begin{tabular}{|l|l|l|}
\hline LANG. & No of Citations & Percent \\
\hline English & 4689 & 92.2 \\
\hline Igbo & 356 & 7.0 \\
\hline French & 16 & 0.3 \\
\hline German & 14 & 0.3 \\
\hline Hausa & 7 & 0.1 \\
\hline Yoruba & 2 & 0.04 \\
\hline TOTAL & 5084 & $\mathbf{9 9 . 9}$ \\
\hline
\end{tabular}

Table 5 presents data for the result of languages of the cited sources generated from the theses. English language is the dominant language of the sources cited (92.2\%) followed by Igbo language sources (one of the major Nigerian languages) with $7 \%$ of the citations. French and German sources received 16 and 14 citations while Hausa and Yoruba sources (two major Nigerian languages) have 7 and two (2) citations, respectively. The findings reveal that scholarly communication among Nigerian language researchers are mainly in English. 
Table 6: Summary of age of the cited sources

\begin{tabular}{|l|l|l|}
\hline Period & Total citations & $\%$ \\
\hline Pre -1900 & 16 & 0.3 \\
\hline $1900-1960$ & 290 & 5.7 \\
\hline $1961-1970$ & 435 & 8.6 \\
\hline $1971-1980$ & 1281 & 25.2 \\
\hline $1981-1990$ & 1475 & 29.0 \\
\hline $1991-2000$ & 957 & 18.8 \\
\hline $2001-2010$ & 460 & 9.0 \\
\hline $2011-2014$ & 123 & 2.4 \\
\hline No Dates & 47 & 0.9 \\
\hline Total & 5084 & \\
\hline
\end{tabular}

The summary of the timeliness of the cited sources is presented in Table 6 . The period 1980s recorded the highest number of citations with 1475 (29\%) followed by 1970 s with 1281 citations (25.2\%). After 1980s, the number citations came down to $957(18.8 \%)$ in the period 1991 to 2000 and 460 (9\%) for the period 2001 to 2010 . The lowest citations were to materials published before 1900.

Table 7: Authorship pattern for language research

\begin{tabular}{|l|l|l|l|l|l|l|l|l|}
\hline S/N & Periods & $\begin{array}{l}\text { Single } \\
\text { Authors }\end{array}$ & $\begin{array}{l}\text { Two } \\
\text { authors }\end{array}$ & $\begin{array}{l}\text { Three } \\
\text { authors }\end{array}$ & $\begin{array}{l}\text { More } \\
\text { than } \\
\text { three } \\
\text { authors }\end{array}$ & $\begin{array}{l}\text { Total } \\
\text { of all } \\
\text { Authors }\end{array}$ & $\begin{array}{l}\text { Percent } \\
\text { of } \\
\text { periods }\end{array}$ & $\begin{array}{l}\text { Collaboration } \\
\text { coefficient }\end{array}$ \\
\hline 1 & Pre-1900 & 12 & 3 & 1 & 0 & 16 & 0.3 & 0.25 \\
\hline 2 & $1900-1960$ & 223 & 52 & 11 & 4 & 290 & 5.7 & 0.23 \\
\hline 3 & $1961-1970$ & 301 & 84 & 47 & 3 & 435 & 8.6 & 0.31 \\
\hline 4 & $1971-1980$ & 871 & 256 & 111 & 43 & 1,281 & 25.2 & 0.32 \\
\hline 5 & $1981-1990$ & 1,007 & 288 & 123 & 57 & 1,475 & 29.0 & 0.32 \\
\hline 6 & $1991-2000$ & 637 & 226 & 67 & 27 & 957 & 18.8 & 0.33 \\
\hline 7 & $2001-2010$ & 298 & 86 & 57 & 19 & 460 & 9.1 & 0.35 \\
\hline 8 & $2011-2014$ & 87 & 21 & 11 & 4 & 123 & 2.4 & 0.29 \\
\hline 9 & No Date & 34 & 9 & 3 & 1 & 47 & 0.9 & 0.28 \\
\hline & Total & $\begin{array}{l}3,470 \\
(68.3 \%)\end{array}$ & $\begin{array}{l}1,025 \\
(20.2 \%)\end{array}$ & $\begin{array}{l}431 \\
(8.5 \%)\end{array}$ & $\begin{array}{l}158 \\
(3.0 \%)\end{array}$ & 5,084 & 100 & 0.32 \\
\hline
\end{tabular}

Data on the authorship pattern are presented in table 7. It can be seen that single authored sources dominate the citations (68.3\%), followed by citations with two authors (20.2\%). Cited sources of three authors recorded $8.5 \%$ while citations of more three authors yielded 3.0\%. The collaboration coefficient is generally low (o.32), however the highest collaboration coefficient was from $2001-2010$ (0.35) with the lowest during the period of 1900 to 1960. 


\section{The degree of collaboration $\mathrm{C}=$}

Where $C$ = Degree of collaboration in a discipline

$\mathrm{Nm}=$ Number of multiple authored papers in a discipline

Ns = Number of single authored papers in a discipline

Therefore, $\mathrm{C}=0.32$

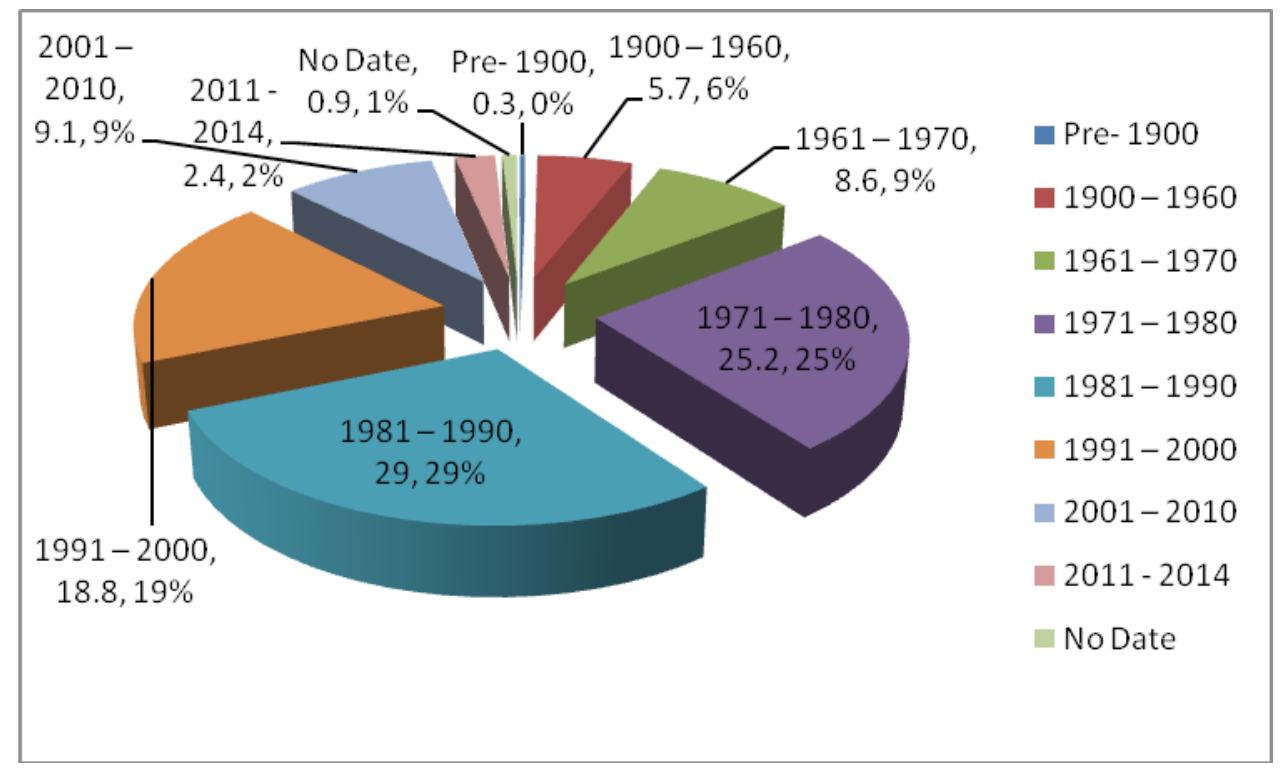

Fig 2: Pie chart showing year wise authorship pattern

Table 8: Rank list of most frequently cited books

\begin{tabular}{|c|c|c|c|c|c|c|}
\hline 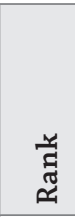 & 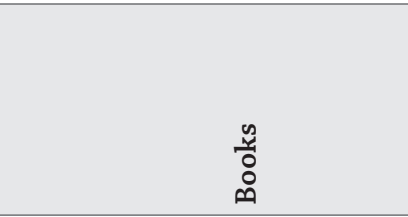 & 泀 & 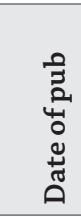 & 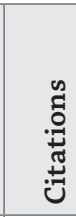 & 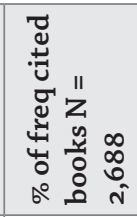 & 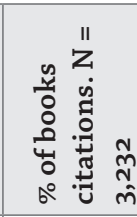 \\
\hline 1 & Aspect of the theory of syntax & Chomsky, N & 1965 & 132 & 4.9 & 4.1 \\
\hline 2 & Yoruba oral tradition & Abimbola, W & 1975 & 121 & $4 \cdot 5$ & 3.7 \\
\hline 3 & Igbo-English dictionary & Williamson, $\mathrm{K}$ & 1972 & 117 & 4.4 & 3.6 \\
\hline 4 & Oral literature in Africa & Finnegan, $\mathrm{R}$ & 1970 & 107 & 4.0 & 3.3 \\
\hline 5 & $\begin{array}{l}\text { Exploration in the functions of } \\
\text { language }\end{array}$ & Halliday, M.A.K & 1977 & 105 & 3.9 & 3.2 \\
\hline 6 & Language of Africa & Greenberg, J.H & 1963 & 102 & 3.8 & 3.2 \\
\hline 7 & $\begin{array}{l}\text { Language, culture and society: } \\
\text { a reader in linguistics and } \\
\text { anthropology }\end{array}$ & Hymes, D.H & 1964 & 100 & 3.7 & 3.1 \\
\hline
\end{tabular}




\begin{tabular}{|c|c|c|c|c|c|c|}
\hline 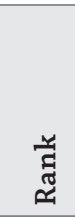 & 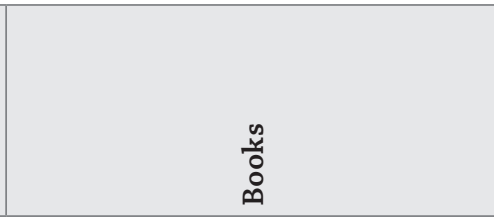 & 㟯 & 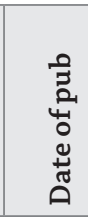 & 苑 & 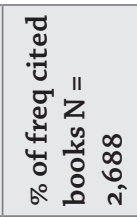 & 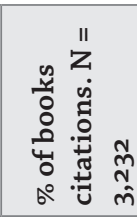 \\
\hline 8 & Olodumare: Gods in Yoruba belief & Idowu, E.B & 1962 & 98 & 3.6 & 3.0 \\
\hline 9 & $\begin{array}{l}\text { Transformational generative } \\
\text { grammar: an introduction. }\end{array}$ & Yusuf, O & 1959 & 96 & 3.5 & 3.0 \\
\hline 10 & Lectures on government binding & Chomsky, N & 1981 & 95 & 3.5 & 2.9 \\
\hline 11 & Literary theory: an introduction & Eagleton, $\mathrm{T}$ & 1983 & 93 & 3.5 & 2.9 \\
\hline 12 & $\begin{array}{l}\text { Knowledge of language, its nature, } \\
\text { origin and use. }\end{array}$ & Chomsky, N & 1986 & 91 & 3.4 & 2.8 \\
\hline 13 & Contents and forms of Yoruba ijala & Babalola, A & 1966 & 90 & 3.4 & 2.8 \\
\hline 14 & $\begin{array}{l}\text { Igbo verbs: a semantic - syntactic } \\
\text { analysis }\end{array}$ & Uwalaka, M.A & 1988 & 88 & 3.3 & 2.7 \\
\hline 15 & $\begin{array}{l}\text { Transformational grammar: a first } \\
\text { course }\end{array}$ & Radford, A & 1988 & 87 & 3.2 & 2.7 \\
\hline 16 & Linguistics & Crystal, D & 1971 & 85 & 3.2 & 2.6 \\
\hline 17 & $\begin{array}{l}\text { Yoruba theatre: introduction to } \\
\text { African theatre }\end{array}$ & Beier, Ulli & 1967 & 83 & 3.1 & 2.6 \\
\hline 18 & Towards an Igbo literary standard & Nwachukwu, P.A & 1983 & 81 & 3.0 & 2.5 \\
\hline 19 & Phonology: theory and analysis & Hyman, L & 1995 & 79 & 2.9 & 2.4 \\
\hline 20 & Sociolinguistics & Trudgill, $\mathrm{P}$ & 1974 & 78 & 2.9 & 2.4 \\
\hline 21 & Features of Yoruba oral poetry & Olatunji, O.O & 1984 & 75 & 2.8 & 2.3 \\
\hline 22 & Yoruba meta language & Awobuliyi, O & 1989 & 74 & 2.8 & 2.3 \\
\hline 23 & Language & Bloomfield, L & 1935 & 72 & 2.7 & 2.2 \\
\hline 24 & The language of Africa & Greenberg, J. & 1963 & 71 & 2.6 & 2.2 \\
\hline 25 & Dictionary of modern Yoruba & Abraham, R.C & 1958 & 70 & 2.6 & 2.2 \\
\hline 26 & $\begin{array}{l}\text { Multilingualism, minority languages } \\
\text { and language policy in Nigeria. }\end{array}$ & Emenajo, E.N & 1990 & 69 & 2.6 & 2.1 \\
\hline 27 & Introduction to Yoruba oral literature & Ogundeji, P.A & 1991 & 68 & 2.5 & 2.1 \\
\hline 28 & The handbook of phonological theory & Goldsmith, J & 1995 & 67 & 2.5 & 2.1 \\
\hline 29 & Traditional Yoruba poetry & Olukoju, E.O & 1992 & 66 & 2.5 & 2.0 \\
\hline 30 & The development of Yoruba novels & Ogunsina, J.A & 1992 & 65 & 2.4 & 2.0 \\
\hline 31 & A short Yoruba grammar & Bamgbose, $\mathrm{A}$ & 1967 & 64 & 2.3 & 1.9 \\
\hline \multicolumn{2}{|c|}{ TOTAL } & & & 2,688 & 100 & $82.9^{*}$ \\
\hline \multicolumn{2}{|c|}{ Percent } & & & & & \\
\hline
\end{tabular}

${ }^{*}$ Percentage citations of the list of frequently cited books 
A rank list of the most frequently cited books is presented in table 8 . A total of 31 books that produced 2,688 citations, which represent $82.9 \%$ of the overall book citations make up the most frequently cited books. Noam Chomsky's book Aspect of the theory of syntax published in 1965 ranked first followed by Yoruba oral tradition by W Abimbola. Igbo-English dictionary and Oral literature in Africa written by K. Williamson and Ruth Finnegan respectively ranked $3^{\text {rd }}$ and $4^{\text {th }}$. A close observation of the Table indicates that most of the books in the ranked list were published between 1960 and 1980. The oldest book in the list is L. Bloomfield's book "Language" published in 1935, while the newest books are L. Hyman's Phonology: theory and analysis and "The handbook of phonological theory" written by J. Goldsmith and all published in 1995.

\section{Discussion}

The findings from this study provide useful knowledge of the citation behaviour and authorship patterns in language research. It is evident from the study that books and monographs are critical research literature for scholarly communication in the field. Though journals, conference/seminar papers, theses and dissertations made remarkable contributions to the cited sources, books and monographs dominated the citations with over sixty percent. This finding gives credence to the earlier studies by Heinzkill (1980), Georga and Cullars (2005) and Gasparotto (2014) who equally found more citations to books and monographs in their separate studies. However, Georgas and Culler recorded lower percentage of books (about 50\%) and monographs than the present study. Similarly, the findings accentuate the position of Thompson that the core materials for humanities research are books and monographs. These findings may not be surprising because journal publication in the humanities was a later development. This has been buttressed by Wiberly and Jones (1989) that the humanities scholars prefer books and monographs to journals as research literature.

An interesting finding from this study is an increase in citations to theses and dissertations at $8 \%$ as against earlier studies such as Georgas and Culler who reported only $3.6 \%$ and Sharada's five percent. In some other citation studies, theses and dissertations were not even reported as they were often lumped with other sources. The reason for this increase among Nigerian linguists may not be clear. Observations from most African countries indicate that research materials are generally scarce because many of the libraries with few exceptions are not well equipped. Consequently, researchers resort to literature sources that are available and theses and dissertations belong to fairly available literature sources. In addition to this, theses and dissertation provide extensive literature review and exemplary design of study which are very useful to graduate students. These have been established by Barry (1997) and Kiondo (2004). 
Electronic resources contributed 781 (15.4\%) of the total citations. Evidently, there has been improvement of citations to e-resources when compared with earlier studies of Harter (1996), Zhang, (1998), Herring (2002) and Jang (2009). However, it is lower than Singh's (2013) finding. Two reasons may account for increased citations to electronic resources. The first reason is the installation of ICT facilities in the university. The second is the acquisition of electronic databases which host many journals in the university library. The citation of more electronic journals than books could be a result of more full text journals on the Internet than full text e-books.

Scholarly communication among Nigerian language researchers is mainly in English. The findings indicate that citation to English language sources contributed over ninety percent of the total citations. Giving the multi-linguistic nature of the country, one would have expected a good percentage of the citations to Nigeria indigenous languages particularly the three major Nigerian languages. However, English dominated the language of the cited sources because it is the official language of the country and equally the language of instruction in the institutions of higher learning. The implication of this is that a greater percentage of research communication in the country is done in English language. Evidently, the finding is not different from that of Riahinia (2010) who found over ninety percent citations to English language sources in a study conducted in the field of Library and Information Science in an Iranian university. One Nigerian language that has fair contribution in the cited sources is Igbo (one of the major Nigerian languages). This contribution is quite obvious because that is the indigenous language used in the location of the university.

Information emanating from the findings indicates that the time of publication of the cited sources ranges from pre $20^{\text {th }}$ century to $21^{\text {st }}$ century. The older materials were mainly publications of well known authors and archives originating from colonial masters that were found very useful in humanities research as has been observed by Wiberly and Jones (1989). Archives are primary information resources which have been found to be very authoritative in substantiating evidence in humanities and social science research.

A close observation of Table 6 reveals that the 1970s and 1980 produced the highest publications cited in the study. One could safely say that 1980s is the golden period of publications in Nigeria. After the 1980 os citations continued to decrease until the period of 2010s. It can be argued that the pattern of citations over the period is a reflection of Nigerian's political and socio economic development within the period. Economically that was the period of oil boom when government was paying attention to education generally and publishing in particular. The period provided an enabling environment for academic activities. Politically, Nigeria had been a civilian democracy just before then (1979 - 1984) and this encouraged academic activities of which publications was 
a very critical component. Shortly after, there was military intervention which was not education friendly, resulting in a drop in publications. It is obvious that materials become more accessible to researchers after few years of their publications when libraries would have acquired and advertised them, using the current awareness mechanisms available to them. In addition to this, the theses studied were produced between 2005 and 2014 which implies that most works published in 2014 were not likely to be cited.

Scholarly communication process in the language is dominated by solo researchers as can be observed from the findings. Single authored publications constitute over sixty percent of the cited sources. This is in line with other studies in the humanities and languages. For instance, Wiberly and Jones reports that the humanities researchers are more likely to work alone and do more extensive literature review than the scientists. On the contrary, other citation studies in the sciences contradict the present finding since more multiple authorship were recorded by Ezema and Asogwa (2012), Kumar and Kumar (2011), Pradhan, Panda and Chandrakar (2011). The finding shows that collaborative coefficient is low. The collaborative coefficient is 0.32 as against 0.75 reported earlier by Vimala and Reddy (1996). This is not surprising as more single authorship suggests low collaboration coefficient.

The rank list of most frequently cited books with their authors was developed since large proportion of the citations was to books and monographs. It could be deceiving if a rank list of journals is developed considering the percentage of citations to the journals. Chomsky's "Aspect of the theory of syntax" ranked first. Published since 1965, the book appears to be a classic in language research all over the world. Surprisingly, all the books regarded as the most frequently cited are over twenty years; and over half of the more than forty years. This lays credence to the assertion of scholars that age does not affect the quality of research literature in languages (see Georgas \& Cullars 2005). Similarly, a close observation of the ranked list of frequently cited books indicates that all are single authored books which corroborate earlier studies which found greater proportion of single authored sources in language research (See Thompson, 2002).

\section{The Implications of the Findings}

This study has examined the scholarly communication patterns of the language researchers in Nigeria. The literature review conducted reveals that much has not been done to determine citation behaviour of language researchers particularly in Nigeria even though language research is very critical to the overall national development. This study has shown that Nigerian researchers in the languages rely heavily on books and monographs. This has very serious implication for libraries when building their collections. Emphasis should be placed on acquisition of relevant books and monographs 
that would adequately support research in the area. Though, citations to non linguistics books which assist in providing context to their research may be found, a careful collection of linguistics books and research monographs would improve review of theories in linguistics research.

Authorship pattern in linguistics is dominated by single authors. In the present information and knowledge economy emphasis on research is shifting from solo to collaborative research. Though evidences from literature have always shown that language research is dominated by single authorship, the researchers could also consider collaboration, for Katz \& Martin and Cummings \& Kiesler (2005) have argued that funding agencies appear to be more interested in funding collaborative research than solo research. If this is the case, language researchers would have greater opportunities in attracting research grants if they key into collaborative research. Observations from the work have also shown that collaborative research reduces cost (since the cost of the research is usually shared among colleagues), time and produces more reliable research outputs.

\section{Conclusion and Recommendations}

Scholarly communication in the languages is essential through books and monographs. Language researchers also find journals as very good channel for scholarly communication. It is also clear from the findings that single authorship patterns dominate most of the sources cited, however, multiple authorships are increasingly being reported in language and linguistics. Like other humanities field age of materials does not really affect their citations and that is why over seventy percent of the cited sources over twenty years old. Based on these findings, this paper recommends that:

- The University libraries in Nigeria should devote sizeable proportion of the vote to the purchase of relevant books and monographs to encourage and sustain research in language and linguistics.

- Nigerian universities should develop their internet infrastructure to assist researchers in accessing electronic resources. In addition to these university libraries should subscribe to online data bases including e-books with rich contents in language and linguistics.

- Researchers in language and linguistics should improve their communication, collaboration and contact to promote multiple authorships across disciplines and geographic areas.

- The librarians who work with graduate students require more opportunities for professional development to assist them in guiding the students. 


\section{References}

Abetrathne, D.K. (2015). Citation analysis of dissertations for collection development. Collection Building, 34(2), pp. 30 - 40. Available at http://dx.doi.org/10.1108/CB-112014-0055 Accessed August 26, 2015.

Aina, L.O and I.S.Y Ajiferuke, I.S.Y (2002). Research methodologies in information science. In L.O Aina (ed.) Research in information science: an African perspective. Ibadan: Stirling-Horden, pp. $32-62$.

Bamgbose, A. (2003). Pride and prejudice in multilingualism and development. In R. Fardon and G. Fumiss (eds.) African languages, development and the state. New York: Taylor and Francis e-Library, pp.33-43.

Banateppanvar, K. and Biradar, B.S. (2013). Citation analysis of doctoral theses in botany submitted to Kuvempu University, India: a case study. Collection Building, 32(1), pp. 12 - 20. Available at http://dx.doi.org/10.1108/01604951311295058 Accessed August 26, 2015.

Barry, C.A. (1997). Information skill for an electronic world: training doctoral research students. Journal of Information Science, 23(3), pp. 225 - 238. Retrieved May 12, 2009 from jis.sagepub.com/content/23/3/225.full.pdf

Borgman, C. and Furner, J. (2002). Scholarly communication and bibliometrics. Annual Review of Information Science and Technology, 36(1), pp. 2-72.

\section{Buchanan, A.L. and Hérubel, J.V.M. "Interdisciplinarity in Historical Studies:} Citation Analysis of the Journal of Interdisciplinary History," LIBRES 4, (2-4), pp. 1-13 http://hegel.lib.ncsu.edu/stacks/serials/libres/libres-v4no2-3-buchananinterdisciplinarity Accessed December 12, 2007.

Council for the Humanities, Arts and Social Sciences (2005). Measures of quality and impact of publicly-funded research in the humanities, arts and social sciences: final report (draft). Retrieved 3/5/o8 from http://www.chass.org.

Council of Graduate Schools (1991). The role and nature of the Doctoral Dissertation: A policy statement. Washington, D.C.: Council of Graduate Schools.

Crawford, G.A. (2013). A citation analysis of the classical philology literature: Implications for collection development. Evidence Based Library and Information Practice, [S.1.], v. 8, n. 2, pp. 214-224, June. 2013. ISSN 1715-720X. Available at: http://ejournals.library.ualberta.ca/index.php/EBLIP/article/view/18598/152011>. Accessed 17th January, 2014. 
Cummings, J.N. and Kiesler, S. (2005). Collaborative research across disciplinary and organizational boundaries. Social Studies of Science 35, 5, pp. 703-22 http://www. jstor.org/stable/25046668 Accessed January 16, 2013.

Dabrishus, M. (2005) The forgotten scholar: classical scholar and periodical use. A Masters Paper Submitted to Faculty of School of Information and Library Science of the University of North Carolina at Chapel Hill (2005). Available at http://etd.ils. unc.edu/dspace/bitstream/1901/185/1/theforgottenscholar.pdf Accessed 13 June, 2008.

Delgadillo, D. and Lynch, B.P. Future Historians: Their quest for information. College and Research Libraries 6o(3), pp. 245-59 http://crl.acrl.org/content/6o/3/245. abstract Accessed June, 2008.

East, J.W. (2006). Ranking journals in the humanities: an Australian case study. AARL. $37(1)$.

Enger, K.B. (2009). Using citation analysis to develop core book collections in academic libraries. Library \& Information Science Research, 31(2), pp. 107-112. Available at http://www.sciencedirect.com/science/article/pii/So740818809000085 Accessed July 82013.

Ezema, I.J. (2011). Building open access institutional repositories for global visibility of Nigeria scholarly publications. Library Review, 6o(6), pp. $473-485$. Available at www.emeraldinsight.com/oo24-2535.htm Accessed January 20, 2014.

Ezema, I.J. and Asogwa, B.E. (2012). Analysis of cited information sources in Nigerian Agricultural Research with emphasis on Animal Health and Production. International Journal of Library and Information Science 4(1), pp. 1-9. http://www. academicjournals.org/IJLIS Accessed February 4, 2012.

Ezema, I.J. and Asogwa, B. E. (2014). Citation analysis and authorship patterns of two Linguistics journals. Portal: Library and the Academy, 14(1), pp. 67 - 85. Available at http://muse.jhu.edu/login?auth=o\&type=summary\&url=/journals/portal_ libraries_and_the_academy/vo14/14.1.ezema.html

Ezema, I. J. and Ugwuanyi, C.F. (2014). Application of citation analysis in the development of core Nigerian languages texts in Nigeria university libraries. Library Philosophy and Practice, (e-journal). Paper 1131. Available at http://digitalcommons. unl.edu/libphilprac/1131

Fardon, R. and Fumiss, G. (2003). Introduction: Frontiers and boundaries-African languages as political environment. In R. Fardon \& G. Fumiss (eds.) African 
languages, development and the state. New York: Taylor and Francis e-Library, pp. 1 -32 .

Fasae, J.K. (2011). Citation analysis of M.Tech theses submitted in the Department of Agricultural Economics and Extension, Federal University of Technology Akure, Nigeria. Collection Building, 30(4), pp. 179 - 183. Available at digitalcommons.unl.edu/ cgi/viewcontent.cgi?article=1815\&context (Accessed August 26, 2015).

Garfield, E. (1978a). 1977 - 1978 A\&HCI most cited authors. Current Contents, (1978). Retrieved on 23/6/o7 from http://www.garfield.library.upenn.edu.

Garfield, E. (1978b). The 300 most cited authors, 1961 - 1976, including co-authors at last: how the names were selected. Current Contents. 28, (1978), 5 - 17. Retrieved 23/6/o7 from http://www.garfield.library.upenn.edu.

Garfield, E. (1983). Is information retrieval in arts and humanities inherently different from that in science? The effect that ISI's citation index for the arts and humanities is expected to on future scholarship. Reprinted in Essay of Information Scientist. Vol. 6, pp. 623-640. Retrieved 23/6/o7 from http://www.garfield.library.upenn.edu

Gasparotto, M. (2014). A ten year analysis of dissertation bibliographies from the Department of Spanish and Portuguese at Rutgers University. Collection Building, 33(3), pp. 86 - 89. Available at http://dx.doi.org/10.1108/CB-03-2014-0017 Accessed August 26, 2015 .

Georgas, H. and Cullars, J. (2005). A citation study of the characteristics of the linguistics literature, College and Research Libraries 66(6), pp. 496-515 http://www. ala.org/acrl/acrlpubs/crljournal/backissue Accessed August 18, 2008).

Gooden, A.M. (2001). Citation analysis of Chemistry doctoral dissertations: An Ohio State University case study. Issues in Science and Technology Librarianship 32 (Fall 2001): 1-16 http://findarticles.com/p/articles/mi Accessed May 12, 2009.

Gilbert, J. (2008). Cultural imperialism revisited: counseling and globalization. Critical Psychology. Available at http:www.jangilbert.co uk. Retrieved March 31, 2010.

Harter, S.P. (1996). The impact of electronic journals on scholarly communication: a citation analysis. The Public Access Computer Systems Review, 7(5), pp. 1 - 16. Retrieved May 6, 2009 from http://epress.lib.uh.edu/pr/v7/n5/hart7n5.html

Heinzkill, R. (1980). Characteristics of references in selected scholarly English Literary Journals, The Library Quarterly 50(3), pp. 352-65 www.jstor.org/stable/4307248 Accessed June 5, 2009. 
Herring, S.D. (2002). Use of electronic resources in scholarly electronic journals: a citation analysis. College \& Research Libraries, 63(4), pp. 334-340.

Jan, R. (2009). Citation analysis of library trends. Webology, 6(1), (2009). Accessed $24^{\text {th }}$ November, 2009 from http://www.webology.ir/2009/v6n1/a67.html

Karisson, F. (1994). Linguistics in the Light of Citation Analysis, (Helsinki: University of Helsinki, 1994) http://www.ling.helsinki.fi/ fkarlsso/virviit2.html Accessed July $16,2008$.

Katz, J.S. and Martin, B.R. (1997). What Is Research Collaboration?" Research Policy 26, pp. 1-18 http://www.rvm.gatech.edu/bozeman/rp/read/41407.pdf Accessed January 16, 2013.

Kiondo, E. (2004). Historical practice in managing theses and dissertations at African universities and university libraries. Paper presented at the Association of African Universities DATAD workshop on Intellectual Property, Governance, Dissemination and Funding Strategies, Accra, Ghana, February 2004, 19-20.

Knievel, J.E. and Kellsey, C. (2005). Citation Analysis for Collection Development: A Comparative Study of Eight Humanities Fields. The Library Quarterly 75(2), pp. 14268 http://www.journals.uchicago.edu/LQ/toc.html Accessed September 22, 2008.

Krishna, N and Jayaraman. (2013). A citation analysis from Ph.D Dissertations submitted in 2013 by the Department of Management Studies at various Universities in India. Indian Journal of Applied Research, 3 (10), 2013. (Retrieved from http://www.theglobaljournals.com/ijar/file.php?val=MjQzMg Accessed January 20, 2014)

Kumar, S. and Kumar, S. (2011). Citation analysis of Journal of Oilseed Research. Proceedings of 8th International CALIBER (March 2-4, 2011), INFLIBNET Centre, Ahmedabad, and Goa University, Goa, India, pp. 512-27.

Leydesdorff, L. (2011). Bibliometrics/Citation networks (preprint version) In George A. Barnett (ed.), The Encyclopedia of Social Networks. New York: Sage, pp. 72-74. Available at arXiv preprint arXiv:1502.06378, 2015 - arxiv.org Accessed May 2, 2016.

Meho, L.I. (2007). The rise and rise of citation analysis. Physics World 20(1), pp. 32-36 http://www.physicsworld.org Accessed July 23, 2008.

Moed, H.F. (2005). Citation analysis in research evaluation. Berlin: Springer.

Nkiko, C. and Adetoro, N. (2007). Pioneer bachelor degree: Citation analysis of Covenant University students' research projects," Library Philosophy and Practice (e-journal) 
Available at http://digital commons.unl.edu/libphi/prac/150 Accessed August 6, 2008.

Ocholla, D.N. and Ocholla, L. (2007). Research in library and information science in South Africa: an analysis of journal research output from 1993 - 2006. Paper presented at the World Library and Information Congress: $73^{\text {rd }}$ IFLA General Conference and Council $19^{\text {th }}-23^{\text {rd }}$ August, Durban South Africa. Accessed August 23, 2008 from http://www.ifla.org/iv/ifla73

Ogundare, M.A. (2004). The role of language teaching in national development. In C.O.E Ankpa (ed.) Language and literature for a better society, pp. 6o-63.

Okiy, R. B. (2003). A citation analysis of Education Dissertations at the Delta State University, Abraka, Nigeria. Collection Building 22(4), pp. 158-61.

Olaoye, A.A. (2009). Language as a tool for global integration and sustainable democracy: an excursion in political linguistics. Ethiop. Journal of Education and Science. 4(2), pp. 79 - 86. Available at http://www.ajol.info/index.php/ejesc/article/view/51679 Accessed June 23, 2015.

Olukoju, A. (2004). The crisis of research and academic publishing in Nigerian Universities. P.T Zeleza and A. Olukoshi (eds.) Africa universities in the twenty-first century, Vol. 2, Dakar: CODESRIA, pp. 363-375.

Pradhan, P, Panda, S. and Chandrakar, R. (2011). Authorship pattern and degree of collaboration in Indian chemistry literature. Proceedings of 8th International CALIBER (March 2-4, 2011): INFLIBNET Centre, Ahmedabad, and Goa University, Goa, India, pp. 692-99.

Riahinia, N. (2010). A citation analysis study of MA dissertations in the library and information science field in universities in Tehran. Library Review, 59(1), pp. 56-64. Accessed May 6, 2010 from www.emeraldinsight.com/oo24-2535.htm

Rufai, A. (2000). Society, culture and language in Nigeria. In S.B Ajulo (ed.) Language in Education and Society. Maiduguri: University of Maiduguri Press, 55-67.

Shaw, D. and Vaughan, w. (2008). Publication and citation patterns among LIS faculty: Profiling a "typical professor". Library \& Information Science Research, 30(1), 47-55. Retrieved July 8, 2013 from http://www.sciencedirect.com/science/article/pii/ So740818807001296

Singh, H. (2013). Citation analysis of Collection Building during 2005 - 2012. Collection Building, 32(3), pp. 89 - 99. Available at http://dx.doi.org/10.1108/CB-12-2012-0056 Accessed August 26, 2015. 
Singh, K.P and Bebi. Citation analysis of Ph.D theses in sociology submitted to the University of Delhi during 1995-2010: A study. DESIDOC Journal of Library \& Information Technology (DJLIT) 33 (4), 2013

Subramanyan, K. (1983). Bibliometric studies of research collaboration: a review. Journal of Information Science 6(1), pp. 33-38

Tannen, D. (1989) Talking Voices: Repetition, Dialogue, and Imagery in Conversational Discourse. Cambridge: Cambridge University Press.

Thompson, J.W (2002) The death of the scholarly monograph in the humanities? Citation Patterns in Literary Scholarship. Libri: International Journal of Library and Information Science, 2, pp. 121-36. Available at http://www.librijournal.org/ pdf/2002-3pp121-136 (Accessed June 5, 2006).

Tonta, Y. and Al, U. (2006). Scatter and obsolesce of journals cited in theses and dissertations of librarianship. Library and Information Science Research. Retrieved on June 52006 from http://eprints.rclis.org/bitstream/10760/9441/1/tonta-allisr-2006.pdf

Trudghill, P. (1983) Sociolinguistics: an introduction to language and society. New York: Penguin.

Udofia, U.I (1997). Selecting veterinary medical periodicals through citation analysis. Library Review. 46 (1-2), pp. 105-112.

University of Nigeria Calendar Editorial Board (2008). University of Nigeria, 2007 2009 Calendar, Enugu.

Vimala, V. and Reddy, P. (1996). Authorship pattern and collaborative research in the field of Zoology. Malaysian Journal of Library \& Information Science 1(2), pp. 43-50.

Wiberley, S.E. and Jones, W.G. (1989). Patterns of information seeking in the Humanities, College and Research Libraries 5o(6), pp. 638-45.

Zhang, Y. (1998). The impact of internet-based electronic resources on formal scholarly communication in the area of library and information science: a citation analysis. Journal of Information Science, 24 (4), pp. 241-254. jis.sagepub.com/content/24/4/241. full.pdfAccessed January 2, 2009

Zwaan, R.A. and Nederhof, A.J. (1990). Some aspects of scholarly communication in Linguistics: An Empirical Study, Language 66, 3 (September 1990): pp. 553-57 http:// www.jstor.org/stable/414612 Accessed December 12, 2008. 